\title{
Regulation of Proteolysis
}

National Cancer Institute

\section{Source}

National Cancer Institute. Regulation of Proteolysis. NCI Thesaurus. Code C20140.

Biochemical and cellular mechanisms involved in Regulation of Proteolysis ensure that hydrolysis of one or more peptide bonds within target proteins by proteolytic enzymes occur at the correct time and location. 